COMMENT

DOI: $10.1057 /$ s41599-017-0056-6

\title{
The global politics of an urban age: creating 'cities for all' in the age of financialisation
}

Enora Robin ${ }^{1} \&$ Frances Brill ${ }^{2}$

\begin{abstract}
Our globalised and increasingly urban world demands an understanding of how ideas about how to build cities travel to become embedded in places. In this context, private actors operating across borders such as investors, real estate developers, international consultants, global construction companies and engineering firms appear as key agents of change in cities. However, real estate developers' interactions with local stakeholders and their role in territorialising global financial strategies have been relatively under-explored in urban studies and global discussions about our 'urban future', especially within discussions on the implementation of the New Urban Agenda (NUA). This paper aims to initiate future research on this topic, providing some preliminary reflections on the role of developers as key transfer agents in the global movement of capital and its anchoring in places through the transformation of the urban built environment. In this way, we hope to offer some clarity on the transnational movement of financial capital to new places and markets, asking how real estate developers contribute to the dissemination of a global capitalist logic across cities, and what challenges this poses to the implementation of the NUA? To do so, the piece brings together insights from policy mobility literature and recent work on the financialisation of urban developments with the aim of critically assessing whether and how some of the key objectives of the NUA can be achieved in a context characterised by heavy involvement by real estate actors in city-making.
\end{abstract}

\footnotetext{
${ }^{1}$ City Leadership Laboratory, Department of Science, Technology, Engineering and Public Policy, University College London, London, W1T 6EY, UK.

${ }^{2}$ Department of Geography, University College London, Pearson Building, Gower Street, London, WC1E 6BT, UK. Correspondence and requests for materials should be addressed to E.R. (email: enora.robin.15@ucl.ac.uk)
} 


\section{Introduction}

ur globalised and increasingly urban world demands an understanding of the interaction between 'global' and 'local' forces that shape the production of urban space. In this context, private actors operating across borders such as investors, real estate developers, international consultants, global construction companies and engineering firms appear as key agents of change in cities. Whilst a lot of discussion around the implementation of the New Urban Agenda (United Nations, 2016) has focused on the need for multi-stakeholder partnerships -including the private, public, non for profit and grassroots sectors-at various scales of governance, these reflexions would benefit from a deeper engagement with issues of how real estate actors positions themselves in urban decision-making networks. These actors are indeed regularly claiming their own 'right to the city' or 'right to develop' (Leffers, 2017) in the parts of the city they own (or do not own). The recent increased interest in the financialisation of urban development in urban scholarly literature (Christophers, 2015; Halbert and Attuyer, 2016; Aalbers, 2017) makes this line of inquiry, linking developers' activities to the implementation of the NUA, particularly pertinent.

Financialisation refers to the increased role of financial institutions in urban decision-making, a shift in governance or rationality which prioritises capitalist ideals through 'shareholder value', and the importance of finance capital investment decisions in shaping what gets built and where (Rutland, 2010). The body of literature addressing these trends examines the important role played by financial and real estate industries in shaping urban trajectories worldwide. In doing so it highlights an increasing reliance on financial capital to fund key housing projects or infrastructure development in cities and how this strengthens the position of real estate actors in urban decision making (Searle, 2014; Rouanet and Halbert, 2016). This, we argue, poses serious challenges for the realisation of the NUA's vision of 'cities for all' (United Nations, 2016, p. 5) in many respects. For instance, studies on the financialisation of housing have linked speculative real estate activities to soaring housing prices (Marcuse and Madden, 2016; Minton, 2013), population displacement, and gentrification in cities of the Global South and the Global North (Smith, 2002). The last 2 years have been marked by an increasing focus on the 'new frontiers' of real estate investment, namely rapidly urbanising countries of Asia and Africa (PwC, 2015; Jones Lang Lasalle, 2015), and the cities within those countries. However, real estate developers' interactions with local stakeholders and their role in territorialising global financial strategies has been relatively under-explored in urban studies and global discussions about our 'urban future', especially within discussions on the implementation of the NUA. Understanding how financial strategies shape urban trajectories, physically and institutionally, and how financial logic travel across space, requires analysis to pay more attention to the modus operandi of these new 'citybuilders' (Fainstein, 2001). In other words, it requires researchers to explore and unpack how financial capital modifies the urban fabric through the mediation of real estate developers' activities.

This commentary piece aims to initiate this line of research, providing some preliminary reflexions on the role of developers as key transfer agents in the global movement of capital and its anchoring in places through the transformation of the urban built environment. To do so, the piece brings together insights from policy mobility literature and recent work on the financialisation of urban developments with the aim to critically assess whether and how some of the key objectives of the NUA (e.g., the imperative of 'leaving no one behind' and of 'providing access to sustainable, affordable, adequate, resilient and safe housing' (United Nations, 2016, p. 24)) can be achieved in a context characterised by the strong involvement of real estate actors in city-making. In this way, we hope to offer some clarity on the transnational movement of financial capital to new places and markets, asking how real estate developers contribute to the dissemination of a global capitalist logic across cities, and what challenges this poses for the implementation of the NUA?

Rather than providing definitive answers, this short commentary aims to show why taking real estate developers seriously matters for current and future academic and policy research on the NUA. The first section calls for a reframing of current research on urban policy mobility, arguing that developers have long been ignored in that literature despite being a key transfer agent of urban development models in cities of the Global North and South alike. The second section highlights how developers are embedded in both the global circulation of capital and strongly entrenched in the city within which they operate (Halbert and Rouanet, 2014), anchoring financial logic in the socioinstitutional context of particular places. The third and final section relates those issues to that of the implementation of the NUA, highlighting some of the challenges posed by the prominence of real estate activities in urban developments-opening up avenues for future research.

\section{Real estate developers as transfer agents in the global flow of urban models}

The realisation of international commitments such as the NUA and SDG11 "Make Cities and human settlements safe, resilient and sustainable" demands attention to be paid to the way in which ideas, policies and urban models move across the globe through a wide range of organisations. Specific actors and institutions have been shown to be vital mediators in these global flows, translating and moving policies into new contexts (Stone, 2004). In doing so they elevate themselves to the role of 'experts' (McCann, 2010) and become an essential component in the global flow of information, ideas and norms about what constitute good urbanism. In that regard, policy mobility literature offers an excellent point of departure for engaging with how the logic of finance travels globally.

On a site-specific level, existing research highlights the role of local policy advisors in the dissemination of urban models (Wood, 2015), while more recent research has responded to calls to move beyond a focus on public sector actors only (Stone, 2004), arguing that consultants and other private sector actors are increasingly part of the global flow of information (Bok and Coe, 2017). At the same time a macro-level analysis has focused on the role played by international bodies (Stone, 2004), including UNHabitat and the World Bank. This research demonstrates such organisations also contribute to the dissemination of urban models and policies, for instance through their promotion of slum upgrading programs (Imparato and Ruster, 2003). Irrespective of the level of analysis, this highlights the role of intermediaries in the global flow of urban ideas (Healey, 2013), demonstrating the necessity of looking at 'who' puts policy into motion and questioning how they do so (Peck, 2011). That said, despite recognition of the importance of real estate developers in governance and internationalised environments (Fainstein, 2001, Halbert and Attuyer, 2016), they have been little explored in urban policy mobility literature, which has tended to focus on the policies in motion (González, 2011; Didier et al., 2013), other travelling agents such as consultants (Prince, 2012, Rapoport and Hult, 2017) and engineers (Rimmer, 1991; Niosi, 1988), or the places where ideas land (McCann, 2008). It is therefore important to consider what moves (policy, idea, norms) and how (through which medium, be that a specific tool for decision making or a specific organisation) more broadly. 
Rapoport and Hult (2017) open discussion to the movement of 'norms' (in that case about sustainable urbanism) and facilitate a shift towards a wider conceptualisation of global flows of knowledge and ideas across places, through the mediation of consulting firms. Such an approach has also emerged implicitly in recent urban studies research focusing on the financialisation of urban development, through its focus on the reliance on investment capital for financing urban infrastructure, housing provision and the maintenance of public space, to name only a few examples. In that regard, not only does financial logic express itself through capital investment in real estate in cities, it is also disseminated through real estate developers' activities and through the use of specific instruments and techniques that put the financial logic at the very heart of decision making (e.g., financial viability assessment for urban development projects; calculation of expected rates of returns, etc) (Guironnet and Halbert, 2014). These are important issues in the context of the NUA, as implementing its various targets, especially in relation to housing provision and inclusivity, could be jeopardised by speculation-driven investments in cities from the Global North and the Global South alike (Goldman, 2011; Li et al, 2014; Goodfellow, 2017). Therefore, it is necessary to understand how the increasing involvement of private real estate developers (and their financial backers) shapes both the physical and institutional environment of the cities where they operate.

\section{Real estate activities and the anchoring of finance capital logic in places}

Whilst a single theory cannot explain how the logic of capital accumulation (Harvey, 1978) manifests in each urban location through a single overarching narrative (Ong and Roy, 2011), it is necessary to recognise that there exists a shared understanding by those working in real estate about how to maximise profits. In recognising the traveling of norms and ideas therefore, it is essential we remain attendant to how financial logic and learnings travel globally too. This calls attention to the role of real estate actors who are pivotal intermediaries between investors (global or local) and places, helping 'land' money from elsewhere in specific location, through their development projects (Halbert and Rouanet, 2014).

When reorienting analysis towards the real estate sector, it is necessary to adopt a relational understanding of actions (Henneberry and Parris, 2013) that facilitates recognition of the way cities are produced and produce global geographies (Massey, 2005). The international flows of urban models and global financial investors strategies are in continual dialogue with local actors and contextual understandings, norms and institutions, all of which significantly influence how models, including financial ones, are interpreted in a given setting, and often result in only part of the policy or idea travelling (Peck, 2011; McCann and Ward, 2011). Therefore, this necessitates paying attention to real estate developers global actions but also, and maybe more importantly, to their territorialised strategies and their local web of interactions.

Developers build their strategies according to their knowledge of the property sector (local property markets and international property cycles), but also their knowledge of the local socioinstitutional context within which their projects are embedded (Healey, 1992). As a result, the stakeholders they need to engage with include a wide range of actors involved in property developments such as construction companies, architects, engineers, investors, planning consultants and many more, as well as local and national public authorities and local community groups. This global/local relational dynamic must be better analysed to show how ideas and norms of urban development travel across space and time. By tracing these movements, it becomes possible to think through a wider conceptualisation of financialisation which encompasses the movement of financial 'norms' (Halbert and Rouanet, 2014) and financial tools for decision making (e.g., financial viability assessment, risk assessment, etc) through real estate developers' activities in cities. Consequently, developers emerge as key mediators in the global movement of not just finance capital itself, but in how financial logic and financialised understandings of space are understood and translated in new places.

\section{Real estate-driven urban development and the NUA: the challenges that lie ahead}

Despite recognition of their influence and importance in urban matters globally, existing analysis of developers' strategies remains relatively thin (Coiacetto, 2001; Campbell et al., 2013). Indeed, if developers are the new 'city builders' (Fainstein, 2001), understanding how they operate and how their activities relate to the implementation of the NUA appears crucial. Their role as translators, relocators, or anchors of global finance and the profit accumulation logics they carry with them poses issues for urban development trajectories, and threatens the objectives of inclusion and the creation of 'cities for all'. This is especially pertinent at a time where developers are being pitched against the public and social housing budgets are decreasing, paving way for developers to move in to new areas, markets and countries where demand is growing and profit is expected. In swapping from traditional locations like high-end London or Manhattan (Fernandez et al., 2016) to these emerging spaces developers take with them the ideas and logics they learnt before.

The movement of ideas within the private sector is facilitated by the club like mentality of the industry (Attuyer et al., 2012). International organisations like the FIABCI (International Real Estate Federation) act as forums for sharing ideas and have been involved in global urban affairs since 1954-when the organisation became accredited with the UN (Scruggs, 2017). Since then it, and other similar organisations, have been advocating specific changes to international frameworks for the urban environment and for property rights to be recognised in international agreements. While the NUA does not go as far as to recognise a universal right to private property, it does acknowledge the importance of private investments for funding urban development. This should be a starting point for engaging with how real estate developers shape the built environment-both far and near to their home cities-and questioning how their relational, transcalar strategies for both urban governance (Halbert and Attuyer, 2016) and capital accumulation can be included in policy analysis for a more just city. The NUA is suggestive of way to tackle the potential issues of increased reliance on institutional real estate investments to finance urban developments, highlighting the need for regulations and taxation schemes that prevent speculation and land value capture which would only benefit speculators:

We will promote best practices to capture and share the increase in land and property value generated as a result of urban development processes, infrastructure projects, and public investments. Measures could be put in place, as appropriate, to prevent its solely private capture as well as land and real estate speculations, such as gains-related fiscal policies. We will reinforce the link among fiscal systems, urban planning, as well as urban management tools, including land market regulations. (United Nations, 2016: p 18). 
Yet such an engagement, whilst highlighting the necessity of moving past private sector only developments, is limited by its understanding of the relational strategies of developers. And more precisely how these strategies straddle places and operate on a global scale, whilst the developers themselves invoke specific localising approaches. There is a need to acknowledge more accurately the consequences, in terms of right to the city, of a globalised and traveling financialised understanding of space captured and moved through the actions of developers.

The logic of capital accumulation travels through an understanding that real estate assets should be valued for their exchange value. In positioning property as a liquid asset (Fernandez et al., 2016) and financialising development projects, real estate actors have played a vital role in shifting what a city is, who projects are built for and what types of property are built (Goodfellow, 2017). The unprecedented shift towards exchange value orientated real estate necessitates paying attention the issues the NUA highlights: private land value capture and speculation. On a local level, this has been done with research consistently demonstrating how speculative action in global cities has changed how cities develop (ibid.) and created an over-inflated housing market (Minton, 2013; Marcuse and Madden, 2016).

What we must be increasingly cautious of, in a world where mobile capital can virtually be invested anywhere, is further exploitation of untapped markets, be those real estate markets of the Global South or lower income segments of established housing markets like London. The global housing affordability crisis has pushed real estate actors (i.e., developers and investors) to reflect on their strategies and relocate their actions. For instance, developers have shifted to look at potential profit gains in the affordable housing market since demand in this sub-sector may indeed surpass demand for products at the higher-end as Danielle Grossbacher, world president of the FIABCI, notes: 'The demand is so big for affordable housing'. For developers then, 'the trick is to find a return on investment reasonably close to what [developers] would get building on Billionaire's Row in New York' (Scruggs, 2017).

\section{Conclusion}

In conclusion and whilst this might seem cynical, at a time where local governments fail to invest in housing infrastructure, and profit making on high-end development is increasingly challenging for developers aiming to make large profit margins in many well supplied markets, some property investors seem more inclined to serve the ever growing demand for affordable housing. This shift, towards 'gap housing' (Butcher, 2016) makes sense from a profit-maximisation perspective, and if we are to create equitable cities in the future we need to recognise how the norms and ideas around capital accumulation drive developers to find new markets to exploit-be these local gap markets or new cities. Critically engaging with those strategies is necessary for national, regional and municipal governments to design legal and institutional frameworks that support the goals of the NUA and provide development through the private sector while preventing speculative investments. Engaged urban scholarship has been focusing on the consequences of financialisation, shedding light on issues related to the right to the city, we argue that this literature would also benefit from engaging with the other side of the spectrumfocusing on what motivates and allows real estate actors to deploy their strategies to ensure their own right to the city, more specifically, their assumed right to benefit from property.

Received: 24 November 2017 Accepted: 4 December 2017 Published online: 09 January 2018

\section{References}

Aalbers MB (2017) The variegated financialization of housing. Int J Urban Reg Res 41:542-554

Attuyer K, Guironnet A, Halbert L (2012) Turning pumpkins into carriages: sustainable urban development and the financialization of 'green' commercial real estate in France. Articulo-J Urban Res 9. https://doi.org/10.4000/ articulo. 2155

Bok R, Coe N (2017) Geographies of policy knowledge: The state and corporate dimensions of contemporary policy mobilities. Cities 63:51-57

Butcher S (2016) Infrastructures of property and debt: making affordable housing, race and place in Johannesburg. Doctoral thesis, University of Minnesota

Campbell H, Tait M, Watkins C (2013) Is there space for better planning in a neoliberal world? Implications for planning practice and theory. J Plan Educ Res 34:45-59

Christophers B (2015) The limits to financialization. Dialog- Human Geogr 5:183-200

Coiacetto E (2001) Diversity in real estate developer behaviour: A case for research. Urban Policy Res 19:43-59

Didier S, Morange M, Peyroux E (2013) The adaptative nature of neoliberalism at the local scale: Fifteen years of city improvement districts in Cape Town and Johannesburg. Antipode 45:121-139

Fainstein SS (2001) The city builders: property development in New York and London, 1980-2000, 2nd ed. University Press of Kansas, Lawrence, rev. edn. Lawrence

Fernandez R, Hofman A, Aalbers MB (2016) London and New York as a safe deposit box for the transnational wealth elite. Environ Plan A 48:2443-2461

Goldman M (2011) Speculative urbanism and the making of the next world city. Int J Urban Reg Res 35:555-581

González S (2011) Bilbao and Barcelona 'in motion'. How urban regeneration 'models' travel and mutate in the global flows of policy tourism. Urban Stud 48:1397-1418

Goodfellow T (2017) Urban fortunes and skeleton cityscapes: real estate and late urbanization in Kigali and Addis Ababa. Int J Urban Reg Res 41(5):786-803

Guironnet A, Halbert L (2014) The financialization of urban development projects: concepts, processes, and implications. Working Paper no. 14-04, $44 \mathrm{pp}$

Halbert L, Attuyer K (2016) Introduction: The financialisation of urban production: Conditions, mediations and transformations. Urban Stud 53:1347-1361

Halbert L, Rouanet H (2014) Filtering risk away: global finance capital, transcalar territorial networks and the (un)making of city-regions: an analysis of business property development in Bangalore, India. Reg Stud 48:471-484

Harvey D (1978) The urban process under capitalism: a framework for analysis. Int J Urban Reg Res 2(1-3):101-131

Healey P (1992) An institutional model of the development process. J Prop Res 9:33-44

Healey P (2013) Circuits of knowledge and techniques: the transnational flow of planning ideas and practices. Int J Urban Reg Res 37:1510-1526

Henneberry J, Parris S (2013) The embedded developer: using project ecologies to analyse local property development networks. Town Plan Rev 84:227-249

Imparato I, Ruster J (2003) Slum upgrading and participation: Lessons from Latin America. World Bank Publications

Jones Lang Lasalle (2015) Emerging beyond the frontier: an overview of subSaharan Africa's real estate capital market. http://www.africa.jll.com/africa/ en-gb/Research/Beyond the Frontier - Africa Report A4 FINAL.pdf. Accessed 22 Nov 2017

Leffers D (2017) Real estate developers' influence of land use legislation in the Toronto region: an institutionalist investigation of developers, land conflict and property law. Urban Stud. https://doi.org/10.1177/0042098017736426

Li Z, Li X, Wang L (2014) Speculative urbanism and the making of university towns in China: A case of Guangzhou University Town. Habitat Int 44:422-431

Marcuse P, Madden D (2016) In defense of housing: the politics of crisis. Verso Books

Massey D (2005) For Space. Sage, London, p 222

McCann E (2010) Urban policy mobilities and global circuits of knowledge: toward a research agenda. Ann Assoc Am Geogr 101:107-130

McCann E, Ward K (eds) (2011) Mobile urbanism: Cities and policymaking in the global age. University of Minnesota Press, Minneapolis

McCann EJ (2008) Expertise, truth, and urban policy mobilities: Global circuits of knowledge in the development of Vancouver, Canada's 'four pillar'drug strategy. Environ Plan A 40:885-904

Minton A (2013) Scaring the living daylight out of people. Spinwatch report. https://sidmouthindependentnews.files.wordpress.com/2013/03/scaring-theliving-daylights-final.pdf

Niosi J (1988) Du nouveau dans les services internationaux: les multinationales de l'ingénierie. Rev D'économie Ind 43:70-82

Ong A, Roy A (eds) (2011) Worlding cities: Asian experiments and the art of being global. Wiley-Blackwell 
Peck J (2011) Geographies of policy: from transfer-diffusion to mobility-mutation. Prog Hum Geogr 35:773-797

Prince R (2012) Policy transfer, consultants and the geographies of governance. Prog Hum Geogr 36:188-203

PwC (2015) Real estate 2020: building the future. https://www.pwc.com/sg/en/realestate/assets/pwc-real-estate-2020-building-the-future.pdf. Accessed $22 \mathrm{Nov}$ 2017

Rapoport E, Hult A (2017) The travelling business of sustainable urbanism: International consultants as norm-setters. Environ Plan A 49:1779-1796

Rimmer P (1991) The global intelligence corps and world cities: engineering consultancies on the move. In: Daniels P (ed) Services and metropolitan development: international perspectives, London: Routledge, pp 66-106.

Rouanet H, Halbert L (2016) Leveraging finance capital: Urban change and selfempowerment of real estate developers in India. Urban Stud 53:1401-1423

Rutland T (2010) The financialization of urban redevelopment. Oxford, UK

Scruggs G (2017) Developers seek affordable-housing market in new urban agenda, citiscope. http://citiscope.org/habitatIII/news/2016/01/developers-seekaffordable-housing-market-new-urban-agenda. Accessed 22 Nov 2017

Searle LG (2014) Conflict and commensuration: contested market making in India's private real estate development sector. Int J Urban Reg Res 38:60-78

Smith N (2002) New globalism, new urbanism: gentrification as global urban strategy. Antipode 34:427-450

Stone D (2004) Transfer agents and global networks in the 'transnationalization' of policy. J Eur Public Policy 11:545-566

United Nations (2016) New Urban Agenda

Wood A (2015) The politics of policy circulation: Unpacking the relationship between South African and South American cities in the adoption of bus rapid transit. Antipode 47:1062-1079

\section{Additional information}

Competing interests: The authors declare no competing financial interests.

Reprints and permission information is available online at http://www.nature.com/ reprints

Publisher's note: Springer Nature remains neutral with regard to jurisdictional claims in published maps and institutional affiliations.

\section{(c) (1)}

Open Access This article is licensed under a Creative Commons Attribution 4.0 International License, which permits use, sharing, adaptation, distribution and reproduction in any medium or format, as long as you give appropriate credit to the original author(s) and the source, provide a link to the Creative Commons license, and indicate if changes were made. The images or other third party material in this article are included in the article's Creative Commons license, unless indicated otherwise in a credit line to the material. If material is not included in the article's Creative Commons license and your intended use is not permitted by statutory regulation or exceeds the permitted use, you will need to obtain permission directly from the copyright holder. To view a copy of this license, visit http://creativecommons.org/ licenses/by/4.0/.

(c) The Author(s) 2018 